\title{
Characterization and In Vitro Cytocompatibility of an Acid-Etched Titanium Surface
}

\author{
Daniel Rey de CARVALHO ${ }^{1}$ \\ Paulo Sérgio Perri de CARVALHO² \\ Osvaldo MAGRO FILHO ${ }^{3}$ \\ José Daniel Biasoli DE MELLO 4 \\ Márcio Mateus BELOTI ${ }^{5}$ \\ Adalberto Luiz ROSA ${ }^{5}$

\begin{abstract}
${ }^{1}$ Department of Oral and Maxillofacial Surgery, Dental School, Catholic University of Brasilia, Brasilia, DF, Brazil ${ }^{2}$ Department of Stomatology, Bauru Dental School, University of São Paulo, Bauru, SP, Brazil

${ }^{3}$ Department of Surgery and Integrated Clinic, Araçatuba Dental School,

São Paulo State University, Araçatuba, SP, Brazil

${ }^{4}$ Laboratory of Tribology and Materials, School of Mechanical Engineering,

Federal University of Uberlândia, Uberlândia, $M G$, Brazil

${ }^{5}$ Cell Culture Laboratory, Ribeirão Preto Dental School, University of São Paulo, Ribeirão Preto, SP, Brazil
\end{abstract}

\begin{abstract}
The aims of this study were to characterize the microstructure of a commercially pure titanium (cpTi) surface etched with $\mathrm{HCl}_{2} \mathrm{H}_{2} \mathrm{SO}_{4}$ (AE-cpTi) and to investigate its in vitro cytocompatibility compared to turned cpTi (T-cpTi). T-cpTi showed a grooved surface and AE-cpTi revealed a surface characterized by the presence of micropits. Surface parameters indicated that the AE-cpTi surface is more isotropic and present a greater area compared to T-cpTi. The oxide film thickness was similar between both surfaces; however, AE-cpTi presented more $\mathrm{Ti}$ and $\mathrm{O}$ and less $\mathrm{C}$. Osteoblastic cell proliferation, alkaline phosphatase activity, and bone-like nodule formation were greater on T-cpTi than on AE-cpTi. These results show that acid etching treatment produced a surface with different topographical and chemical features compared to the turned one, and such surface modification affected negatively the in vitro cytocompatibility of cpTi as demonstrated by decreasing culture growth and expression of osteoblastic phenotype.
\end{abstract}

Key Words: cytocompatibility, cell culture, osteoblast, titanium, surface treatment.

\section{INTRODUCTION}

The interaction between the biomaterials surface and osteoblasts is strongly associated with the biocompatibility of orthopedic and dental implants (1). The connection of implants and surrounding tissues, mainly bone, is of great interest to research on biomaterials and a significant number of studies have been carried out to investigate promising improvements of the bone/biomaterials interface (1-3). Titanium (Ti) is largely used as an implant biomaterial due to its mechanical properties and high in vitro and in vivo cytocompatibility, allowing direct bone-to-implant contact (4).
In an attempt to improve the amount and quality of the bone-implant interface, surface treatments such as surface machining, acid etching, electropolishing, anodic oxidation, sandblasting or plasma-spraying may be undertaken to induce chemical modifications associated with alterations in surface topography (5). It has been shown that methods of implant preparation can significantly affect the properties of the surface and subsequently the biologic response that occur at the surface (6). Chemical treatments, such as acid etching of the Ti implant surfaces, are of particular interest because they appear to have the potential to greatly enhance osseointegration without embedding surface 
contaminants - e.g. grit particles (4). Treatment of Ti with a mixture of $\mathrm{H}_{2} \mathrm{SO}_{4} / \mathrm{H}_{2} \mathrm{O}_{2}$ produces a surface that affects events of in vitro osteogenesis, leading to an increase in bone-like nodule formation, as well as more boneto-implant contact in vivo (2). Sandblasted Ti surfaces, etched with $\mathrm{HCl}$ and $\mathrm{H}_{2} \mathrm{SO}_{4}$ favored events related to osteoblastic differentiation (7). As most studies have evaluated the combination of acid etching with other surface treatments, the present study was designed to characterize the microstructure of a commercially pure $\mathrm{Ti}$ (cpTi) surface, only etched with $\mathrm{HCl}$ and $\mathrm{H}_{2} \mathrm{SO}_{4}$, and to evaluate its cytocompatibility by investigating key parameters of the development of osteoblastic phenotype in cultures of cells derived from human alveolar bone fragments grown on this surface.

\section{MATERIAL AND METHODS}

\section{Preparation of cpTi Discs}

Discs of grade four cpTi were obtained from commercial bar stock with $12 \mathrm{~mm}$ diameter and were cut to a height of $3 \mathrm{~mm}$. The discs were subjected to the following treatments: T-cpTi, turned (control surface); and AE-cpTi, turned followed by acid etching in $60 \% \mathrm{H}_{2} \mathrm{SO}_{4}$ and $70 \%$ $\mathrm{HCl}\left(60^{\circ} \mathrm{C}, 1 \mathrm{~h}\right)$. Before use in the cell culture experiments, all samples were thoroughly rinsed with deionized water under continuous agitation for $20 \mathrm{~min}$ to eliminate acid residues and sterilized by gamma-irradiation.

\section{Surface Characterization of cpTi Discs}

Surface topography was evaluated with a scanning electron microscopy (SEM, XL30; Philips, Eindhoven, Netherlands). Surface parameters were obtained by laser interferometry (Microfocus Expert IV; UBM Corporation, Sunnyvale, CA, USA). A predetermined area $(2 \times 2 \mathrm{~mm})$ was evaluated and data were analyzed using the Mountains Map Universal software (Digital Surf Sarl 3.0; Besancon, France) to determine surface design. Surface chemical composition and oxide film thickness were evaluated by X-ray photoelectron spectroscopy (XPS; VSW HA 100-VSW, Scientific Instrument Ltda, Manchester, UK).

\section{Culture of Osteoblastic Cells}

Human alveolar bone fragments (explants) were obtained from healthy donors, using the research protocols approved by the local Research Ethics Committee. Osteoblastic cells were obtained from these explants by enzymatic digestion using collagenase type II (Gibco Life Technologies, Grand Island, NY, USA). These cells were cultured in $\alpha$-minimum essential medium (Gibco), supplemented with $10 \%$ fetal bovine serum (Gibco), 50 $\mu \mathrm{g} / \mathrm{mL}$ gentamicin (Gibco - Life Technologies), $0.3 \mu \mathrm{g} /$ mL fungizone (Gibco), 10-7 M dexamethasone (Sigma, St. Louis, MO, USA), $5 \mu \mathrm{g} / \mathrm{mL}$ ascorbic acid (Gibco), and $7 \mathrm{mM} \beta$-glycerophosphate (Sigma). Subconfluent cells in primary culture were harvested after treatment with $1 \mathrm{mM}$ ethylenediamine tetraacetic acid (EDTA) (Gibco) and $0.25 \%$ trypsin (Gibco) and subcultured in 24-well culture plates (Falcon; Franklin Lakes, NJ, USA) on T-cpTi and AE-cpTi discs at a cell density of $2 \times 10^{4}$ cells per disc. Cells subcultured in wells without cpTi discs were used as a control of culture conditions. During the culture period, cells were incubated at $37^{\circ} \mathrm{C}$ in a humidified atmosphere of $5 \% \mathrm{CO}_{2}$ and $95 \%$ air. The medium was changed every 3 or 4 days.

\section{Cell Adhesion}

In this assay, cells were cultured for $24 \mathrm{~h}$, enzymatically ( $1 \mathrm{mM}$ EDTA, $1.3 \mathrm{mg} / \mathrm{mL}$ collagenase type II, and $0.25 \%$ trypsin; Gibco) detached and counted using a haemocytometer (Housser Scientific Company, Horsham, PA, USA). Cell adhesion was expressed as a percentage of the initial number of cells $\left(2 \times 10^{4}\right.$ cells per disc $)$.

\section{Cell Proliferation and Viability}

In this assay, cells were cultured for 1 and 7 days, and counted as described above. At 7 days, viable and non-viable cells were detected by trypan blue, which dyed in blue non-viable cells, and counted using a haemocytometer (Housser Scientific Company). Cell proliferation was expressed as doubling time in hours between 1 and 7 days, and cell viability was expressed as a percentage of the viable cells counted at 7 days.

\section{Alkaline Phosphatase (ALP) Activity}

At days 7, 14, and 21, ALP activity was assayed as the release of thymolphthalein from thymolphthalein monophosphate using a commercial kit (Labtest Diagnóstica SA, Lagoa Santa, MG, Brazil). The wells were 
filled with $2 \mathrm{~mL}$ of $0.1 \%$ sodium lauryl sulfate (Sigma) and left for $30 \mathrm{~min}$ at room temperature. After this, 50 $\mu \mathrm{L}$ of thymolphthalein monophosphate was mixed with $0.5 \mathrm{~mL}$ of diethanolamine buffer, $0.3 \mathrm{mmol} / \mathrm{mL}, \mathrm{pH}$ 10.1 , and left for $2 \mathrm{~min}$ at $37^{\circ} \mathrm{C}$. Then, it was added 50 $\mu \mathrm{L}$ of the lysates from each well. This stood for $10 \mathrm{~min}$ at $37^{\circ} \mathrm{C}$ and then $2 \mathrm{~mL}$ of a solution of $\mathrm{Na}_{2} \mathrm{CO}_{3} 0.09$ $\mathrm{mmol} / \mathrm{mL}$ and $\mathrm{NaOH} 0.25 \mathrm{mmol} / \mathrm{mL}$ was added to allow color development. After $30 \mathrm{~min}$, absorbance was measured at $590 \mathrm{~nm}$ and ALP activity was calculated from a standard curve using thymolphthalein to give a range from 0.012 to $0.40 \mu \mathrm{mol}$ thymolphthalein $/ \mathrm{h} / \mathrm{mL}$. Results were calculated and data were expressed as ALP activity normalized by the total protein content.

\section{Bone-Like Nodule Formation}

After culturing for 21 days, cells were washed 3 times with PBS at $37^{\circ} \mathrm{C}$. The attached cells were fixed in $10 \%$ formalin for $2 \mathrm{~h}$ at room temperature and rinsed once in the same buffer. After fixation, the specimens were dehydrated through a graded series of alcohol and stained with Alizarin red S (Sigma), which stains areas rich in calcium. Images of cpTi discs were blind scored by 5 independent observers, using a scale of absent -0 , small - 1, moderate - 2, and large - 3. A morphological and chemical analysis of the nodules were also done by SEM and energy dispersive X-ray spectroscopy (EDS; Carls Zeiss, DSM 940A, Jena, Germany).

\section{Statistical Analysis}

Data of in vitro cytocompatibility presented in this work are the representative results of 2 separate experiments in cell cultures established from 2 different donors. Thirty-five samples of each surface were used for each separate experiment, with 5 discs (quintuplicates; $\mathrm{n}=5$ ) for both T-cpTi and AE-cpTi surfaces, for each assay and period evaluated. Comparisons were done using the nonparametric Mann-Whitney U-test, for independent samples at 5\% significance level, and the results were presented as mean \pm standard deviation.

\section{RESULTS}

\section{Surface Characterization of $c p T i$}

The panel of SEM micrographs on Figure 1
(A-D) shows surface characterization of cpTi . At low magnification, $\mathrm{T}-\mathrm{cpTi}$ exhibited grooves resulting from turning process (Fig. 1A). Acid etching treatment eliminates such grooves as observed in AE-cpTi surface (Fig. 1C). High magnification only evidenced the grooves presented on T-cpTi surface (Fig. 1B), while AE-cpTi revealed a surface characterized by the presence of micropits (Fig. 1D).

Three-dimensional axonometric plots and surface directionality of T-cpTi and AE-cpTi are presented in Figure 2. Visually, both groups exhibited distinct surface features. When Figure 2A is compared to 2C and Figure $2 \mathrm{~B}$ is compared to $2 \mathrm{D}$, it can be observed that AE-cpTi was more homogeneous and exhibited a greater isotropy, as indicated by directionality.

The evaluated surface parameters (Table 1) confirmed important differences between both cpTi. Although presenting quite equivalent amplitude parameters, the difference in isotropy was significantly high $(\mathrm{T}-\mathrm{CpTi}=17.4 \%, \mathrm{AE}-\mathrm{cpTi}=91.5 \%)$.

Less usual and more sophisticated hybrid and functional parameters also showed a great dissimilarity between the surfaces in particular the developed interfacial area ratio-Sdr- (204\%) and the surface bearing index at $5 \%$ bearing area ratio-Sbi- $(227 \%)$. The oxide film thickness was very similar between T-cpTi and AE-cpTi surfaces (5.5 and $5.0 \mathrm{~nm}$ respectively). In addition, alteration on the surface chemical composition was observed after acid etching treatment as demonstarted in Table 2. The amount of $\mathrm{C}$ and $\mathrm{S}$ was decreased while $\mathrm{Na}, \mathrm{O}$ and $\mathrm{Ti}$ were increased on AE-cpTi.

\section{Cell Culture Experiments}

Cell attachment was not affected $(\mathrm{p}>0.05)$ by surface treatment of cpTi (Fig. 3). Cell proliferation rate was greater $(\mathrm{p}<0.05)$ on $\mathrm{T}-\mathrm{cpTi}$ as indicated by the lower doubling time compared to AE-cpTi (Fig. 4). Surface treatment of cpTi did not affect $(\mathrm{p}>0.05)$ cell viability (Fig. 5).

The ALP activity was higher $(\mathrm{p}<0.05)$ on T-cpTi compared to AE-cpTi in all evaluated periods, namely 7 , 14, and 21 days (Fig. 6). The T-cpTi surface supported more $(\mathrm{p}<0.05)$ the formation of bone-like nodules than the AE-cpTi (Fig. 7). Nodules observed under SEM exhibited a multiglobular aspect (Fig. 8A) and were composed by $\mathrm{Ca}$ and $\mathrm{P}$ (Fig. 8B). 

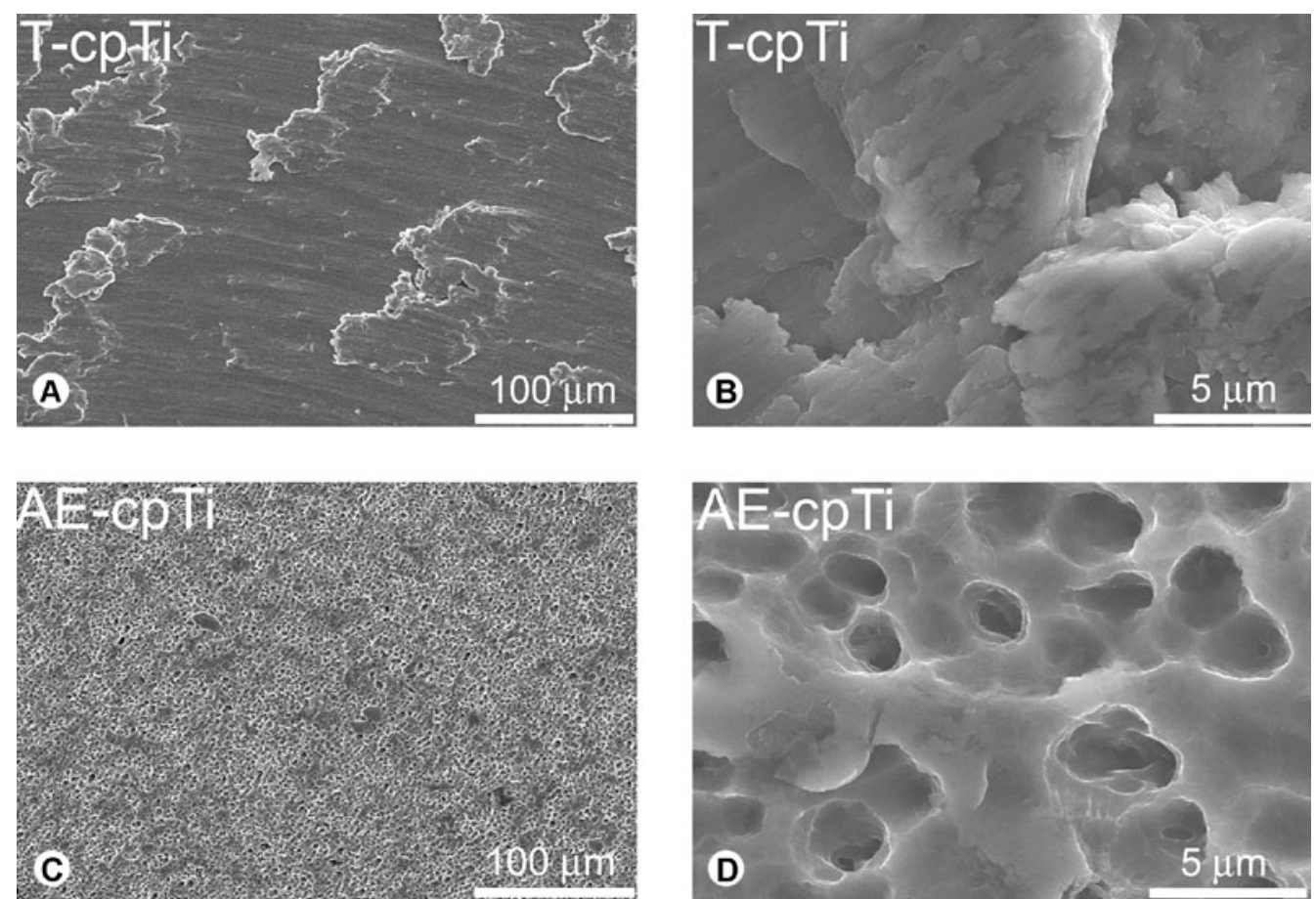

Figure 1. High-resolution scanning electron micrographs of the T-cpTi (A and B) and AE-cpTi (C and D) surfaces. T-cpTi exhibited grooves resulting from turning process $(\mathrm{A})$. Acid etching treatment eliminates the grooves $(\mathrm{C})$. At high magnification, T-cpTi showed grooves (B) and AE-cpTi revealed a surface with micropits (D). Original magnification: $A, C=500 \times ; B, D=10000 \times$.

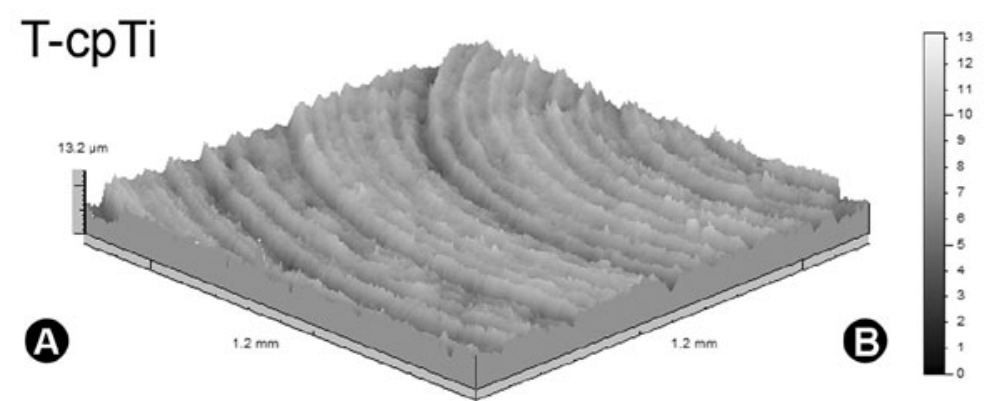

T-cpTi
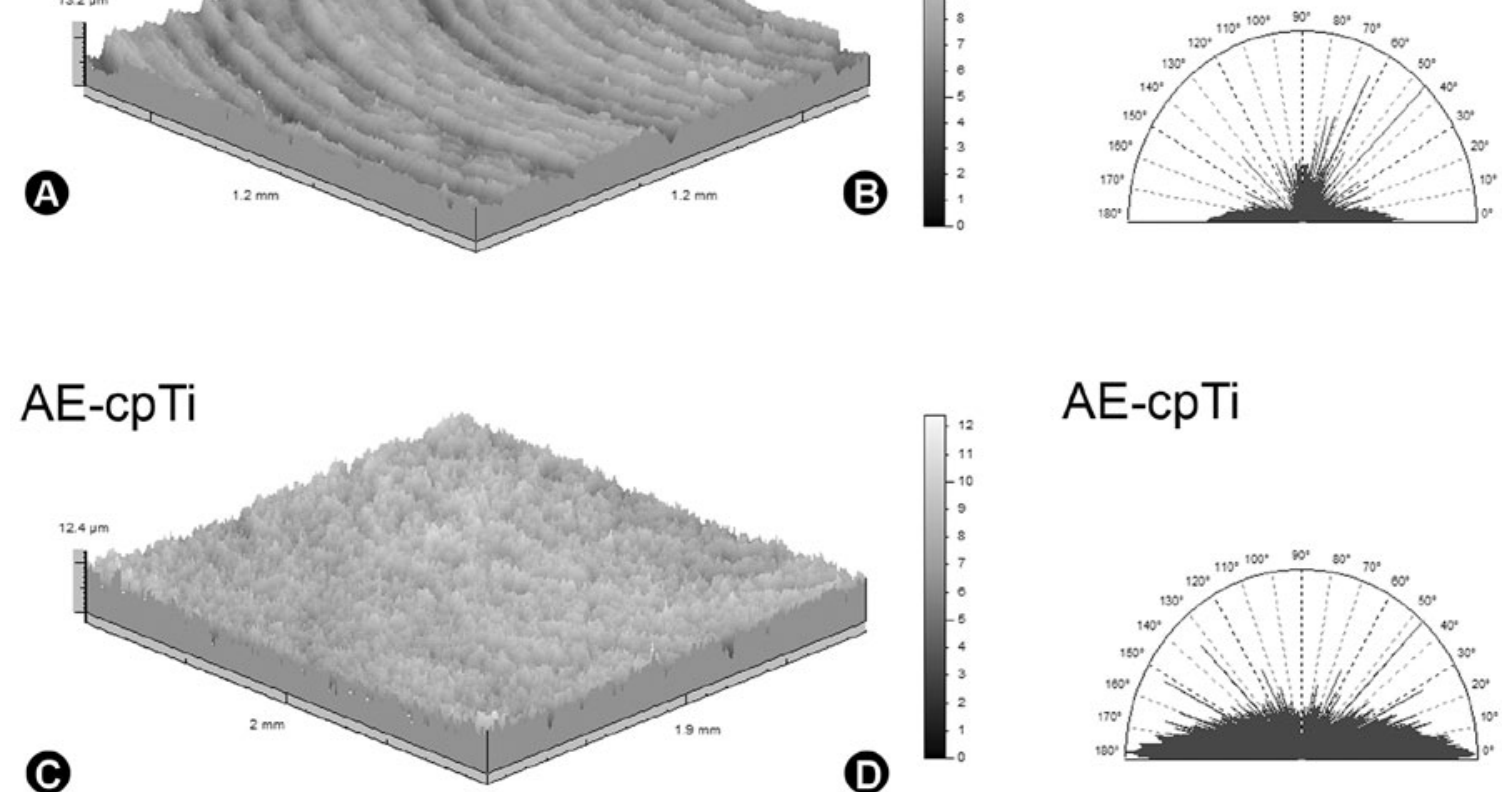

AE-cpTi

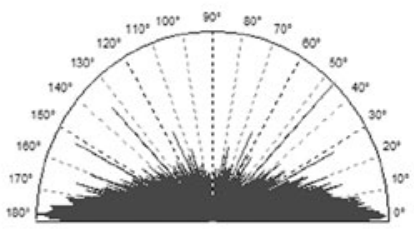

Figure 2. Three-dimensional axonometric plots of T-cpTi (A) and AE-cpTi (C) and surface directionality of T-cpTi (B) and AE-cpTi (D). 
Table 1. Surface parameters of T-cpTi and AE-cpTi.

\begin{tabular}{lccc}
\hline & & T-cpTi & AE-cpTi \\
\hline Amplitude & Sa $(\mu \mathrm{m})$ & 0.90 & 0.97 \\
parameters & Sq $(\mu \mathrm{m})$ & 1.15 & 1.17 \\
& Ssk & -0.12 & -0.48 \\
& Sku & 4.47 & 3.15 \\
$\begin{array}{l}\text { Hybrid } \\
\text { parameters }\end{array}$ & Sdq $\left(\mu \mathrm{m} \mu \mathrm{m}^{-1}\right)$ & 0.16 & 0.27 \\
& $\mathrm{Ssc}\left(1 \mu \mathrm{m}^{-1}\right)$ & 0.20 & 0.27 \\
& $\mathrm{Sdr}(\%)$ & 1.72 & 3.52 \\
$\begin{array}{l}\text { Functional } \\
\text { parameters }\end{array}$ & Sbi & 0.18 & 0.41 \\
& Sci & 1.42 & 1.33 \\
$\begin{array}{l}\text { Surface } \\
\text { directionality }\end{array}$ & Svi & 0.13 & 0.14 \\
\hline & & & \\
\hline
\end{tabular}

T-cpTi - turned commercially pure titanium; AE-cpTi - acid-etched commercially pure titanium; Sa - average roughness; Sq - square mean roughness; Ssk - Skewness; Sku - Kurtosis; Sdq - root mean square (rms) surface slope comprising the surface; Ssc - mean summit curvature comprising the summits found for the Sds calculations; Sdr - developed interfacial area ratio expressed as the percentage of additional surface area contributed by the texture as compared to an ideal plane the size of the measurement region; Sbi - surface bearing index: measure, relative to Sq, of the surface height at the $5 \%$ bearing area ratio; Sci - core fluid retention index: measure, relative to Sq, of the volume the surface would support from $5 \%-80 \%$ of the bearing ratio; Svi - valley fluid retention index: measure relative to the Sq of the volume the surface would support from $80 \%$ to $100 \%$ of the bearing ratio.

Table 2. Chemical composition of T-cpTi and AE-cpTi surfaces.

\begin{tabular}{lcc}
\hline Content (\%) & T-cpTi & AE-cpTi \\
\hline $\mathrm{C}$ & 52.44 & 41.04 \\
$\mathrm{Na}$ & 0.96 & 2.34 \\
$\mathrm{O}$ & 30.31 & 37.72 \\
$\mathrm{~S}$ & 5.57 & 3.28 \\
$\mathrm{Si}$ & 1.35 & 1.47 \\
$\mathrm{Ti}$ & 9.37 & 14.15 \\
\hline
\end{tabular}

T-cpTi - turned commercially pure titanium; AE-cpTi - acid-etched commercially pure titanium.

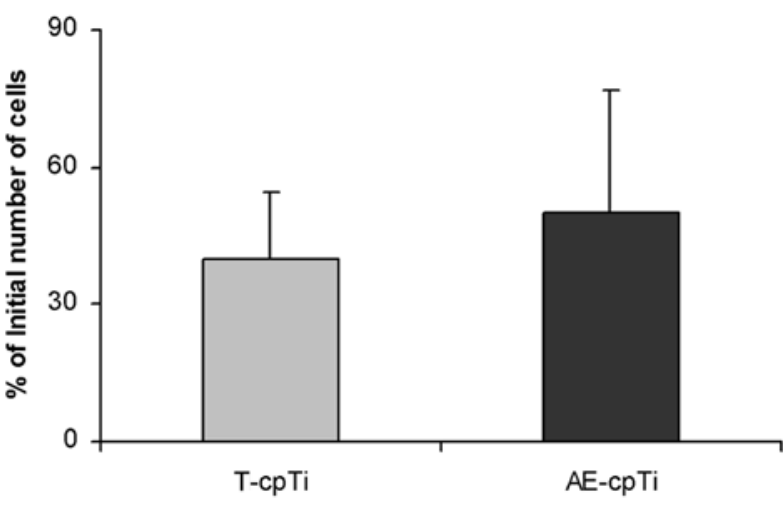

Figure 3. Cell adhesion expressed as a percentage of initial number of cells at $24 \mathrm{~h}$. Attachment was not affected $(\mathrm{p}>0.05)$ by cpTi treatment. The experiment was done with 5 discs of each surface (T-cpTi and AE-cpTi). Data are presented as mean \pm standard deviation.

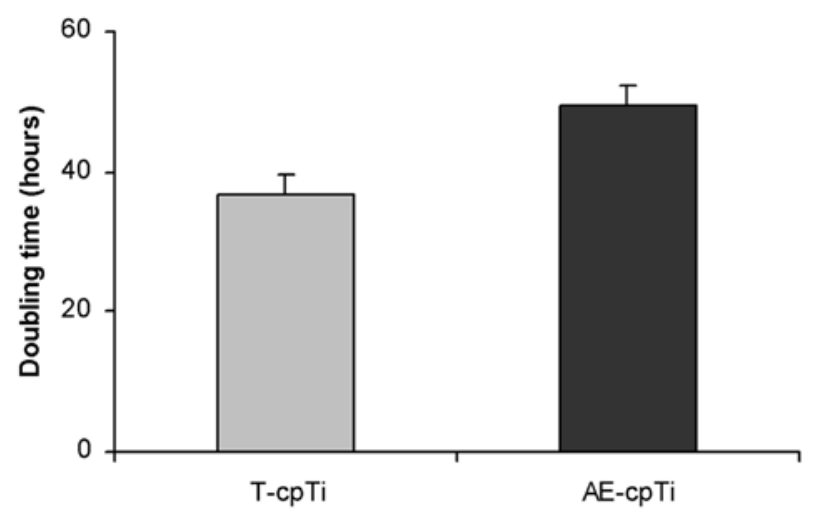

Figure 4. Cell proliferation expressed as doubling time in hours between 1 and 7 days. Cell proliferation rate was higher $(\mathrm{p}<0.05)$ on T-cpTi surface, as indicated by the lower doubling time. The experiment was done with 5 discs of each surface, T-cpTi and $\mathrm{AE}-\mathrm{cpTi}$, and data are presented as mean \pm standard deviation.

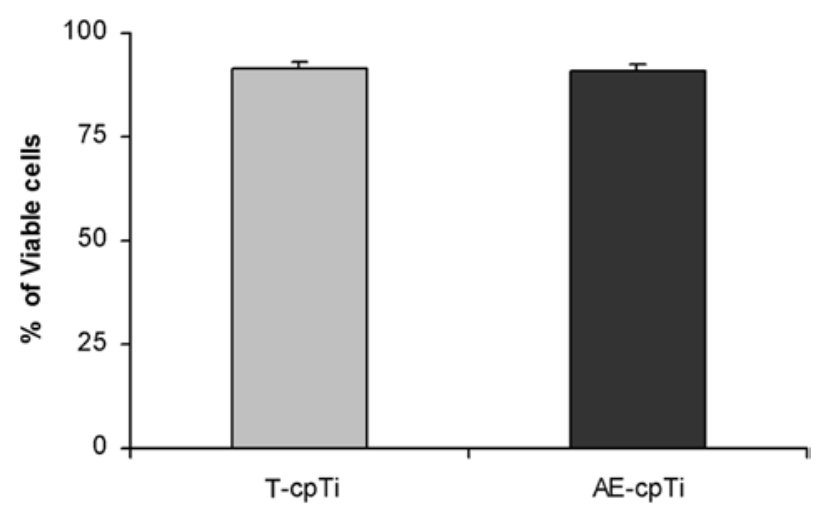

Figure 5. Cell viability expressed as a percentage of viable cells at 7 days. Viability was not affected ( $p>0.05$ ) by cpTi surface treatment. The experiment was done with 5 discs of each surface (T-cpTi and AE-cpTi). Data are presented as mean \pm standard deviation. 


\section{DISCUSSION}

Initial investigations of the osteoblast-biomaterials interactions were essentially focused on the cell re-

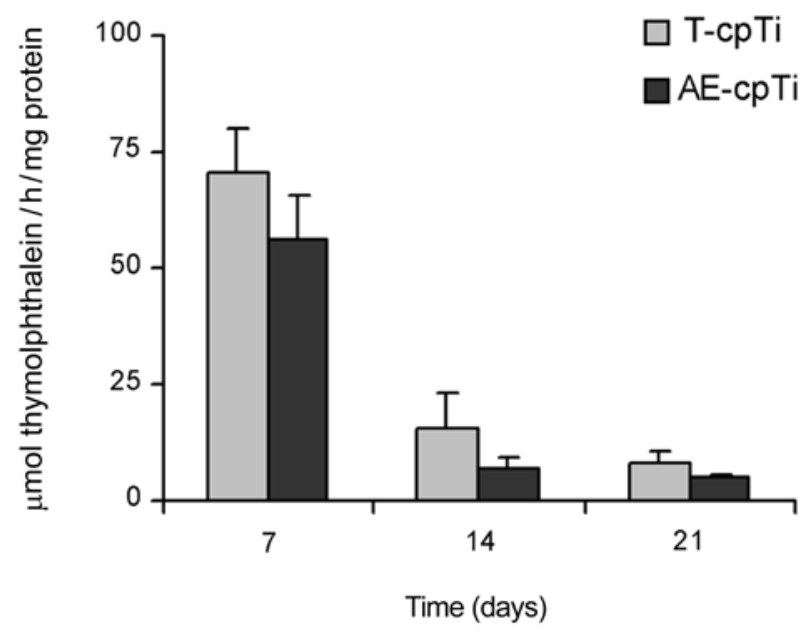

Figure 6. Alkaline phosphatase (ALP) activity ( $\mu$ mol thymolphthalein $/ \mathrm{h} / \mathrm{mg}$ protein) of osteoblastic cells cultured on T-cpTi and AE-cpTi for 7, 14, and 21 days. ALP activity was significantly higher $(\mathrm{p}<0.05)$ in cultures grown on T-cpTi surface in all evaluated periods. The experiment was done with 5 discs of each surface (T-cpTi and AE-cpTi). Data are presented as mean \pm standard deviation. sponse to a diverse range of materials with little attention being paid to the influence of surface characterization. However, it is now well established that surface properties of the biomaterials such as topography, chemistry, and surface energy direct cell-implant interactions (8). Although Ti has been used as a successful implant material, a large number of studies has evaluated variations in the Ti surface properties. In this context, the present

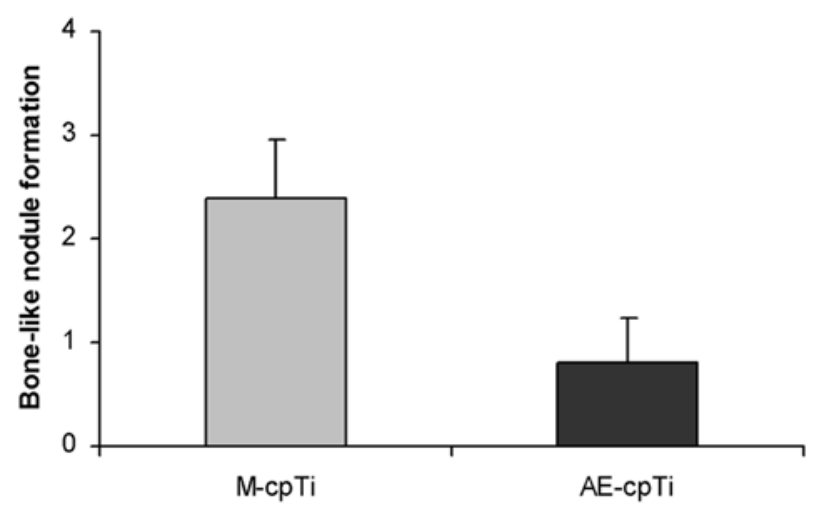

Figure 7. Bone-like nodule formation on T-cpTi and AE-cpTi at 21 days. The amount of matrix mineralization was greater $(\mathrm{p}<0.05)$ on T-cpTi surface. The experiment was done with 5 discs of each surface (T-cpTi and AE-cpTi). Data are presented as mean \pm standard deviation.
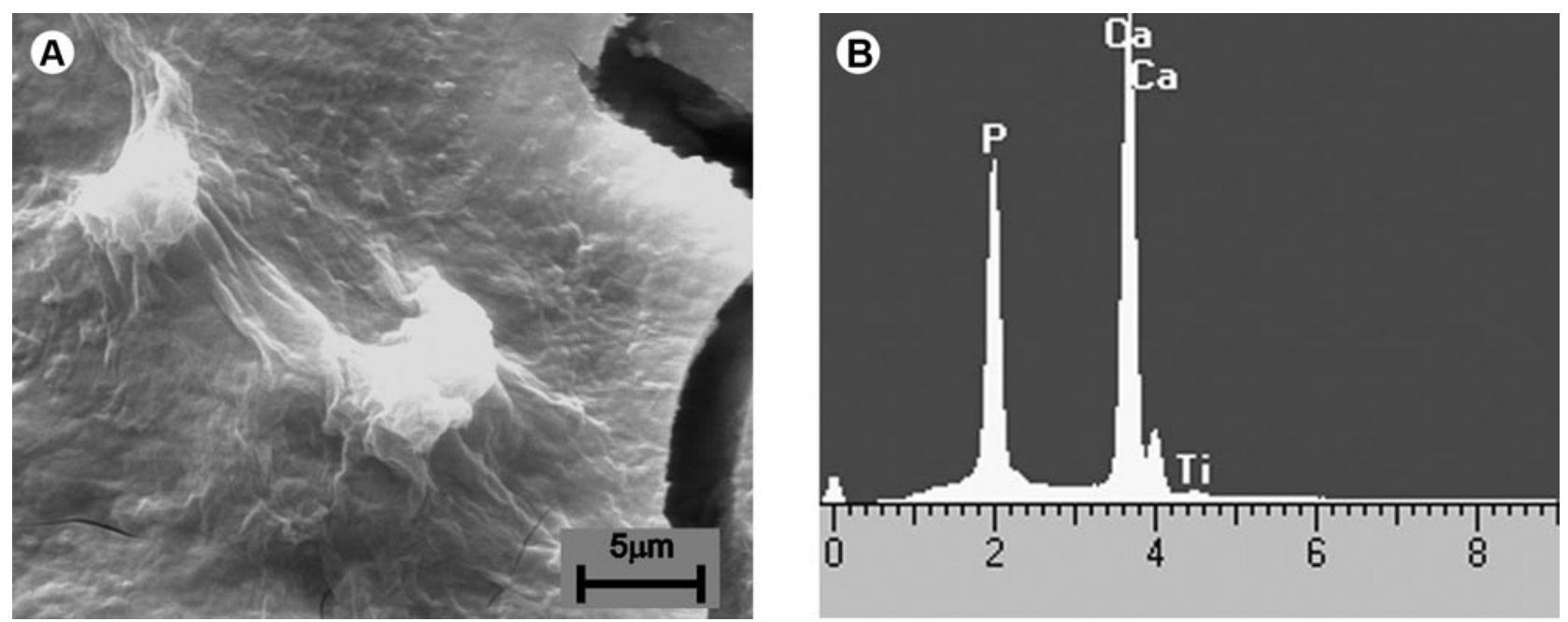

Figure 8. High-resolution scanning electron micrograph and X-ray microanalysis of bone-like nodule. A multiglobular aspect was exhibited by the nodules (A) and it was composed by $\mathrm{Ca}$ and $\mathrm{P}(\mathrm{B})$. 
study aimed to characterize and evaluate the in vitro cytocompatibility of an acid-etched cpTi surface. The results showed that the acid etching treatment used here produced a surface with different topographical and chemical features compared to the turned one (control). In addition, such surface modifications affected negatively the in vitro cytocompatibility of cpTi as demonstrated by decreasing the culture growth and the expression of osteoblast phenotype.

In vitro studies have shown that osteoblastic cells exhibit roughness-dependent phenotypic features, with a tendency to attach more readily and be more differentiated on surfaces with a rougher microtopography (9). The design of the surface also plays a role. On a randomly rough surfaces produced by grit blasting or chemical etching, cells may exhibit a distinct phenotype from that seen on the grooved surface with the same values of surface roughness (10). Additionally to the topographical features, surface chemistry should be taken into account as a variable that may affect cell responses. Cell source and seeding density may also affect the interaction between cells and biomaterials. Bone cells obtained from rat cannot always substitute cells acquired from human tissues and therefore are of limited use (11). Human bone cell lines or bone cells isolated from sites not associated with the oral cavity may not be suitable for studies directed toward dental applications (12). Therefore, compared to other studies, the cell culture model employed here is closer to the cell population, which implants will interact in the clinical circumstances. Considering the same degree of surface roughness as evidenced by $\mathrm{Sa}$ and $\mathrm{Sq}$ values, the same cell source and seeding density, any difference in cell responses found in this study must have occurred as a consequence of differences in the topography and chemical composition between T-cpTi and AE-cpTi surfaces.

The main objective of the treatment with $\mathrm{HCl}$ and $\mathrm{H}_{2} \mathrm{SO}_{4}$ is to etch Ti samples to acquire a large surface area with a relatively thick and stable oxide layer (13). The present results demonstrated that such treatment removed the grooves produced by turning process and created a surface with randomly distributed pits in a micron-scale, enlarging the surface area as evidenced by isotropy and Sdr values. For the formation of focal attachments by cells on 2 or more peaks, a suitable distance between peaks should be maintained; otherwise, the cell would not recognize such surface feature (10). In the present study, the amount of peaks and valleys may have been one of the variables that affected cell responses. Indeed, the values indicated that the T-cpTi surface is almost symmetrical, in which the number of peaks and valleys is equivalent. In addition, the value of Ssk for AE-cpTi is slightly negative indicating a certain predominance of valleys. Although the thickness of oxide layer was similar on both surfaces, chemical composition was different. Such difference could be attributed to the surface treatment employed, which promotes the decrease in $\mathrm{C}$ and the increase in $\mathrm{Ti}$ and $\mathrm{O}$ concentrations. As $\mathrm{C}$ is the most abundant contaminant, it is possible to speculate that acid treatment removed part of the $\mathrm{C}$ from the surface, exposing Ti to react with $\mathrm{O}$ to form the oxide layer.

The cell culture experiments demonstrated that both cpTi surfaces, regardless of the topography and chemical composition, are cytocompatible, considering that they allowed cell attachment, proliferation and a high proportion of viability, synthesis of extracellular matrix proteins and bone-like nodule formation. It has been shown that the initial interaction between cells and biomaterials produces a layer of macromolecules that mediate cell attachment and spread, and such events are not affected by materials with different degrees of cytocompatibility and surface topography (14). In agreement with this, differences in surface features between T-cpTi and AE-cpTi did not influence cell adhesion; however, as initial attachment is not necessarily direct correlated with cell proliferation and differentiation, it is important to investigate cell-biomaterial interactions at later time points.

The amount of in vitro bone-like formation is strongly determined by the rate of replication of osteoprogenitors, the number of active osteoblasts and their life-span (15). Our results demonstrated that T-cpTi, the surface that exhibited a higher cell proliferation rate, also showed higher ALP activity and more bone-like nodule formation compared to AE-cpTi. In agreement with this, it has been shown that an experimental grooved surface favored the osteoblastic phenotype development compared to an acid-etched surface in cultures of cells derived from periostal layer of calf metacarpals (16). In addition, a previous study of our research group found more mineralized matrix on a turned surface than on an acid-etched surface in cultures of rat bone marrow cells (17). Based on our findings, it is possible to speculate that a higher incidence of valleys associated with alterations in the surface chemical composition may negatively 
influence events related to in vitro osteogenesis. However, whether such events are inhibited directly by the physicochemical modifications produced by acid etching treatment and/or indirectly by alterations in the pattern of adsorption of serum proteins remain to be determined.

Treatment with acids produces a range of Ti surfaces with specific features, which may induce different in vitro cell responses. It has been demonstrated that treatment with $\mathrm{HNO}_{3}$ for increasing the thickness of the oxide layer has no effect on Ti cytocompatibility, (18) while treatment with $\mathrm{H}_{2} \mathrm{SO}_{4} / \mathrm{H}_{2} \mathrm{O}_{2}$ produces a surface with nanopits that favor in vitro osteogenesis (2). In vivo studies have shown that chemically etched implant surfaces, using $\mathrm{HCl} / \mathrm{H}_{2} \mathrm{SO}_{4}$ and $\mathrm{HF} / \mathrm{HNO}_{3}$, conferred a greater resistance to reverse torque removal than that of turned surfaces, suggesting higher bone-to-implant contact $(4,19)$. However, a possible explanation for the positive effect of such surface treatments on in vivo experiments could be the greater implant surface area produced, which allows an increased initial stability of the implant (20). In addition, direct comparisons of in vitro and in vivo cell/tissue responses to Ti surfaces are difficult because the number and complexity of factors, such as cell density and microenvironment, which may vary between these conditions.

In conclusion, the results of the present study showed that acid etching treatment produced a surface with different topographical and chemical features compared to the turned one, and such surface modification affected negatively the in vitro cytocompatibility of cpTi as demonstrated by decreasing culture growth and expression of osteoblastic phenotype. However, further studies should be carried out to evaluate the in vivo bone response to this surface.

\section{RESUMO}

O objetivo deste estudo foi caracterizar a microestrutura de uma superfície de titânio comercialmente puro (cpTi) condicionada com $\mathrm{HCl} / \mathrm{H}_{2} \mathrm{SO}_{4}$ (acid etched) (AE-cpTi) e investigar sua citocompatibilidade in vitro, comparada à do cpTi usinado (turned) (TcpTi). OT-cpTi apresentou uma superfície com sulcos e o AE-cpTi exibiu uma superfície caracterizada pela presença de micro-vales. Os parâmetros de superfície indicaram que a superfície AE-cpTi é mais isotrópica e apresenta uma área maior quando comparada à superfície T-cpTi. A espessura da camada de óxido foi similar para as duas superfícies; no entanto, a AE-cpTi apresentou maiores quantidades de Ti e $\mathrm{O}$ e menor, de $\mathrm{C}$. A proliferação de células osteoblásticas, a atividade de fosfatase alcalina e a formação de matriz mineralizada foram maiores na superfície T-cpTi que na AE-cpTi. Esses resultados mostram que o condicionamento ácido produziu uma superfície com características topográficas e químicas diferentes quando comparadas às da superfície usinada. Além disso, observou-se que essas modificações de superfície afetaram de forma negativa a citocompatibilidade in vitro do cpTi como demonstrado pela inibição da proliferação celular e da expressão do fenótipo osteoblástico.

\section{ACKNOWLEDGEMENTS}

The authors would like to thank Roger Rodrigo Fernandes and Junia Ramos for their helpful assistance during the cell culture experiments.

\section{REFERENCES}

1. Brama M, Rhodes N, Hunt J, Ricci A, Teghil R, Migliaccio S, et al. Effect of titanium carbide coating on the osseointegration response in vitro and in vivo. Biomaterials 2007;28:595-608.

2. De Oliveira PT, Zalzal SF, Beloti MM, Rosa AL, Nanci A. Enhancement of in vitro osteogenesis on titanium by chemically produced nanotopography. J Biomed Mater Res A 2007;80:554564.

3. Rosa AL, De Oliveira CS, Beloti MM, Xavier SP, De Oliveira PT. Effect of microcapsules containing TAK-778 on bone formation around osseointegrated implants: histomorphometric analysis in dogs. Implant Dent 2006;15:97-103.

4. Klokkevold PR, Nishimura RD, Adachi M, Caputo A. Osseointegration enhanced by chemical etching of the titanium surface. A torque removal study in the rabbits. Clin Oral Implants Res 1997;8:442-447.

5. Takebe J, Ito S, Champagne CM, Cooper LF, Ishibashi K. Anodic oxidation and hydrothermal treatment of commercially pure titanium surfaces increases expression of bone morphogenetic protein-2 in the adherent macrophage cell line J774A. J Biomed Mater Res A 2007;80:711-718.

6. Keller JC, Draughn RA, Wrightman JP, Dougherty WJ, Meletiou SD. Characterization of sterilized CP titanium implant surfaces. Int J Oral Maxillofac Implants 1990;5:360-369.

7. Kieswetter K, Schwartz Z, Hummert TW, Cochran DL, Simpson J, Dean DD, et al.. Surface roughness modulates the local production of growth factors and cytokines by osteoblast-like MG-63 cells. J Biomed Mater Res 1996;32:55-63.

8. Brunski JB, Puleo DA, Nanci A. Biomaterials and biomechanics of oral and maxillofacial implants: current status and future developments. Int J Oral Maxillofac Implants 2000;15:15-46.

9. Boyan BD, Batzer R, Kieswetter K, Liu Y, Cochran DL, Szmuckler-Moncler $\mathrm{S}$, et al.. Titanium surface roughness alters responsiveness of MG63 osteoblast-like cells to 1a,25-(OH)2D3. J Biomed Mater Res 1998;39:77-85.

10. Lincks J, Boyan BD, Blanchard CR, Lohmann CH, Liu Y, Cochran DL, et al.. Response of MG63 osteoblast-like cells to titanium and titanium alloy is dependent on surface roughness and composition. Biomaterials 1998;19:2219-2232.

11. Mailhot JM, Borke JL. An isolation and in vitro culturing method for human intraoral bone cells derived from dental implant preparation sites. Clin Oral Implants Res 1998;9:43-50.

12. Kasperk C, Wergedal J, Strong D, Farley J, Wangerin K, Gropp $\mathrm{H}$, et al.. Human bone cell phenotypes differ depending on their skeletal site of origin. J Clin Endocrinol Metab 1995;80:25112517. 
13. Wen HB, Liu Q, De Wijn JR, De Groot K, Cui FZ. Preparation of bioactive microporous titanium surface by a new two-step chemical treatment. J Mater Sci Mater Med 1998;9:121-128.

14. Rosa AL, Beloti MM. Effect of cpTi surface roughness on human bone marrow cell attachment, proliferation, and differentiation. Braz Dent J 2003;14:16-21.

15. Jilka RL, Weinstein RS, Bellido T, Roberson P, Parfitt AM, Manolagas SC. Increased bone formation by prevention of osteoblast apoptosis with parathyroid hormone. J Clin Invest 1999;104:439446.

16. Jayaraman M, Meyer U, Buhner M, Joos U, Wiesmann HP. Influence of titanium surfaces on attachment of osteoblast-like cells in vitro. Biomaterials 2004;25:625-631.
17. Xavier SP, Carvalho PS, Beloti MM, Rosa AL. Response of rat bone marrow cells to commercially pure titanium submitted to different surface treatments. J Dent 2003;31:173-180.

18. Faria AC, Beloti MM, Rosa AL. Nitric acid passivation does not affect in vitro biocompatibility of titanium. Int J Oral Maxillofac Implants 2003;18:820-825.

19. Cho SA, Park KT. The removal torque of titanium screw inserted in rabbit tibia treated by dual acid etching. Biomaterials 2003;24:3611-3617.

20. Skalak R, Zhao Y. Interaction of force-fitting and surface roughness of implants. Clin Implant Dent Rel Res 2000;2:219-224.

Accepted March 2, 2010 